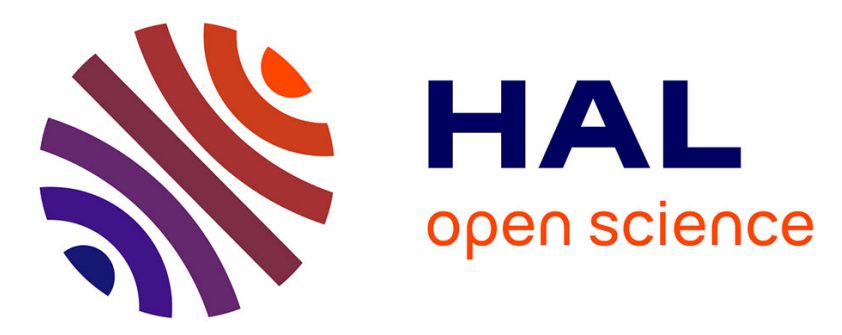

\title{
Improved yield and nutrient efficiency in two globe artichoke genotypes by balancing nitrogen and phosphorus supply
}

\author{
Ierna, Rosario Mauro, Mauromicale
}

\section{To cite this version:}

Ierna, Rosario Mauro, Mauromicale. Improved yield and nutrient efficiency in two globe artichoke genotypes by balancing nitrogen and phosphorus supply. Agronomy for Sustainable Development, 2012, 32 (3), pp.773-780. 10.1007/s13593-011-0048-7 . hal-00930520

HAL Id: hal-00930520

https://hal.science/hal-00930520

Submitted on 1 Jan 2012

HAL is a multi-disciplinary open access archive for the deposit and dissemination of scientific research documents, whether they are published or not. The documents may come from teaching and research institutions in France or abroad, or from public or private research centers.
L'archive ouverte pluridisciplinaire $\mathbf{H A L}$, est destinée au dépôt et à la diffusion de documents scientifiques de niveau recherche, publiés ou non, émanant des établissements d'enseignement et de recherche français ou étrangers, des laboratoires publics ou privés. 


\title{
Improved yield and nutrient efficiency in two globe artichoke genotypes by balancing nitrogen and phosphorus supply
}

\author{
Anita Ierna • Rosario Paolo Mauro • \\ Giovanni Mauromicale
}

Accepted: 27 July 2011 /Published online: 7 September 2011

(C) INRA and Springer Science+Business Media B.V. 2011

\begin{abstract}
Efficient fertilization is a central topic in sustainable agriculture since fertilization strongly influences both crop performances and environmental impact. In several Mediterranean regions, globe artichoke fertilization is still empirically oriented toward nitrogen overdressing and insufficient phosphorus supply. To date, there is a lack of systematic research on the relationships between nitrogen and phosphorus fertilizations, especially in terms of nutrient efficiency. Here, in a 2-year experiment, we studied the effects of two phosphorus fertilization rates, 50 and $150 \mathrm{~kg} \mathrm{P} \mathrm{O}_{5} \mathrm{ha}^{-1}$, and four nitrogen fertilization rates, 0 , 150,300 and $450 \mathrm{~kg} \mathrm{Nha}^{-1}$, on earliness, yield characteristics and nutrient efficiency indices of two globe artichoke genotypes: the traditional vegetatively propagated 'Violetto di Sicilia' and the modern 'seed'-propagated 'Opal $F_{1}$ '. The nutrient efficiency indices included partial factor productivity of nitrogen $\left(\mathrm{PFP}_{\mathrm{N}}\right)$, total factor productivity (TFP) and nitrogen agronomic efficiency $\left(\mathrm{N}_{\mathrm{AE}}\right)$. Results show that the highest phosphorus rate allowed to reduce nitrogen supply from 450 to $300 \mathrm{~kg} \mathrm{ha}^{-1}$ without compromising earliness or yield of the crop. The highest phosphorus rate also increased $\mathrm{PFP}_{\mathrm{N}}$ up to $6.9 \mathrm{~kg}$ heads dry weight ha ${ }^{-1} \mathrm{~kg}^{-1}$ and $\mathrm{N}_{\mathrm{AE}}$ up to $2.5 \Delta \mathrm{kg}$ dry weight $\mathrm{ha}^{-1} \mathrm{~kg}^{-1}$, thus indicating a better nitrogen utilization of the crop, especially at lower
\end{abstract}

\footnotetext{
A. Ierna

Istituto per i Sistemi Agricoli e Forestali del Mediterraneo -

Sezione di Catania, CNR,

Str.le V. Lancia, Zona Industriale Blocco Palma I,

95121 Catania, Italy

R. P. Mauro $\cdot$ G. Mauromicale $(\square)$

Dipartimento di Scienze delle Produzioni Agrarie e AlimentariSezione Scienze Agronomiche, Università degli Studi di Catania, via Valdisavoia 5,

95123 Catania, Italy

e-mail: g.mauromicale@unict.it
}

doses. 'Opal $F_{1}$ ', as compared to 'Violetto di Sicilia', showed higher $\mathrm{PFP}_{\mathrm{N}}$ of 8.1 versus $5.2 \mathrm{~kg}$ heads dry weight ha ${ }^{-1} \mathrm{~kg}^{-1}$ and TFP of 4.0 versus $2.4 \mathrm{~kg}$ heads dry weight $\mathrm{ha}^{-1} \mathrm{~kg}^{-1}$, especially at low nitrogen supplies. We conclude that balancing nitrogen and phosphorus supplies, together with the adoption of globe artichoke genotypes characterized by more efficient utilization of soil mineral nutrients, are effective tools to promote both yield performances and a more sustainable nitrogen fertilization of the crop.

Keywords Cynara cardunculus L. Mineral fertilization . Earliness $\cdot$ Heads number $\cdot$ Head weight $\cdot$ Crop sustainability

\section{Introduction}

The growing utilization of nitrogen $(\mathrm{N})$ fertilizers, starting from the early 1960s, has become one of the primary concerns in sustainable agriculture both in developed and developing nations, given the role of $\mathrm{N}$ as a pollutant involved in ecosystems, biodiversity and food safety deterioration (Ehaliotis et al. 2010; Spiertz 2010). On the other hand, because of the central role of this macronutrient in determining crop growth and yield capability, $\mathrm{N}$ fertilization is perceived as essential in those agricultures not devoted merely to subsistence production (Bhattacharyya et al. 2008; Gonzalez-Dugo et al. 2010). With a view to ensuring high and stable crop yield in a sustainable way, today it is imperative to optimize the efficiency of using chemical $\mathrm{N}$ fertilizers in farmland. According to White and Brown (2010), there are two paths to achieve these targets: an agronomical one, aiming at improving fertilization practices, and a genetic one, aiming at spreading the cultivation of genotypes that acquire soil mineral elements more effectively. 
Mediterranean soils are largely characterized by high amounts of native potassium $(\mathrm{K})$, but low organic matter and, therefore, low $\mathrm{N}$ reserves and mineralization potential (Ryan 1998). As a consequence, $\mathrm{N}$ fertilization is considered indispensable to improve crop productivity (Ryan et al. 2008). On the other hand, the high limestone content characterizing many soils of this region is often at the root of the strong positive responses of the crops to phosphorus (P) fertilization (Ryan et al. 2008). This leads to pivotal practical applications for $\mathrm{N}$ fertilization management because crop requirements may show a strong dependence upon the combined effect of $\mathrm{P}$ and $\mathrm{N}$ available in the soil (Zubillaga et al. 2002).

In Southern Europe, globe artichoke [Cynara cardunculus L. var. scolymus (L.) Fiori] represents an important resource for the agricultural economy (Mauro et al. 2009). The species is a herbaceous, high N-demanding perennial plant, belonging to the Asteraceae family, whose edible inflorescences (heads or capitula) represent a minority fraction of the total aboveground dry matter (Elia and Conversa 2007). Over recent years, thanks also to its reputation as a functional food (Pandino et al. 2010), globe artichoke cultivation is being grown in many parts of the world, especially in Asia (mainly in China, 10.0 kha), South America (Peru, Chile and Argentina, with 7.7, 5.0 and $4.7 \mathrm{kha}$, respectively) and North Africa (Egypt and Morocco, with 7.7 and $4.1 \mathrm{kha}$, respectively; FAOSTAT 2008). Italy is the leading artichoke producer worldwide (50.0 out of 133.0 kha cultivated in the World and a mean annual production of about $480 \mathrm{kt}$ of heads), followed by Spain (16.0 kha and $200 \mathrm{kt})$ and France $(9.5 \mathrm{kha}$ and $45 \mathrm{kt}$; FAOSTAT 2008). In Italy, the crop is mainly present in irrigated farmland of southern regions (Apulia, Sicily, Sardinia) through the cultivation of ancient, vegetatively propagated genotypes (e.g. 'Violetto di Sicilia', 'Violetto Spinoso di Palermo', 'Violet de Provence') which, despite their relatively low yields, are able to ensure high economic gains, most of all thanks to their marked earliness and long productive cycle (from October-November to April; Mauromicale et al. 2004). Overall, the species is usually grown on coastal plains, on a wide range of soil types (Elia and Conversa 2007), but often characterized by poor $\mathrm{N}$ and available $\mathrm{P}$ content, and moderate to high $\mathrm{K}$ and calcium content. Globe artichoke growers mainly adopt $\mathrm{N}$ fertilization, which is commonly reputed to be the primary tool to increase both earliness and yield of the crop, while P fertilization, in order to reduce the cultural costs, is often effected at reduced rates. This leads to irrational fertilization management of the crop, especially regarding $\mathrm{N}$, for which application rates higher than $700 \mathrm{~kg} \mathrm{ha}^{-1}$ are frequently applied (Magnifico 1987). On the other hand, unlike for K fertilization, the experimental results obtained in different productive areas show many discrepancies in the optimal application rates of $\mathrm{P}$ fertilizers, as they strongly depend on soil characteristics, cropping practices, climatic conditions and genotypes (Elia and Conversa 2007). With reference to this last aspect, the recently developed 'seed'-propagated cultivars show a better utilization of soil mineral and water, so virtually allowing the implementation of more sustainable fertilization programs (Cosentino and Mauromicale 1990; Basnizki and Zohary 1994; Mauromicale and Ierna 1995, 2000). Despite some contributions dealing with globe artichoke response to mineral fertilization (e.g. Khayyo et al. 2004; Foti et al. 2005; Rincón et al. 2007), no attempts have been focused to date on defining the $\mathrm{N}$ and $\mathrm{P}$ relationships in this crop, especially in terms of nutrient efficiency, which, instead, may represent a more useful framework toward a sustainable fertilization practice for this crop.

The goal of the present study was to evaluate the effects of different $\mathrm{N}$ and $\mathrm{P}$ fertilization rates, as well as the interaction of both mineral nutrients, on earliness, yield characteristics and nutrient efficiency in two different genotypes of globe artichoke, with the aim of reaching a more sustainable fertilization management of globe artichoke crop in a Mediterranean environment.

\section{Materials and methods}

\subsection{Experimental site}

A field experiment was conducted over two growing seasons (2003/2004 and 2004/2005) on the coastal plain South of Siracusa (South-eastern Sicily, $37^{\circ} 03^{\prime} \mathrm{N}, 15^{\circ} 18^{\prime} \mathrm{E}$, 15 ma.s.1.), an area where globe artichoke cultivation is common. The local climate is characterized by mild wet winters and warm dry summers; winter frosts are rare (two events over 30 years). The moderately deep soil was a Calcixerollic Xerochrepts (USDA, Soil Taxonomy), which, at the beginning of the experiment comprised 30\% clay, $25 \%$ silt, $45 \%$ sand, $2 \%$ organic matter, $21.7 \%$ total limestone, $1.6 \%$ total nitrogen, $68 \mathrm{~kg} \mathrm{ha}^{-1}$ assimilable $\mathrm{P}_{2} \mathrm{O}_{5}$ and $539 \mathrm{~kg} \mathrm{ha}^{-1}$ exchangeable $\mathrm{K}_{2} \mathrm{O}$. The soil $\mathrm{pH}$ was 7.8 , its moisture capacity was $29 \%\left(0.34 \mathrm{~m}^{3} \mathrm{~m}^{-3}\right)$ of dry soil, and its wilting point was $11 \%\left(0.13 \mathrm{~m}^{3} \mathrm{~m}^{-3}\right)$. All soil analyses were performed according to procedures approved by the Italian Society of Soil Science (Società Italiana Scienza del Suolo 1985).

\subsection{Experimental design and crop management}

A split plots design with four replications was adopted, involving two phosphorus fertilization rates $(50$ and $150 \mathrm{~kg} \mathrm{ha}^{-1}$ of $\mathrm{P}_{2} \mathrm{O}_{5}$, hereafter referred to as $\mathrm{P}_{50}$ and $\mathrm{P}_{150}$, respectively) as the main plots, four $\mathrm{N}$ fertilization rates $(0$, 
150,300 and $450 \mathrm{~kg} \mathrm{ha}^{-1}$ of $\mathrm{N}$, hereafter referred to as $\mathrm{N}_{0}$, $\mathrm{N}_{150}, \mathrm{~N}_{300}$ and $\mathrm{N}_{450}$, respectively) as sub-plots and two globe artichoke genotypes (the Italian traditional 'Violetto di Sicilia' and the hybrid cultivar 'Opal $\mathrm{F}_{1}$ ') as sub-subplots. 'Violetto di Sicilia' is an autochthonous varietal type, which has represented the main cultivated germplasm in South Italy for decades, owing to its earliness and adaptability (Mauromicale and Ierna 2000; Portis et al. 2005). In the Mediterranean environment, its productive period starts in October-November and ends in April. Moreover, it shows similar biological characteristics to other widespread cultivars in Europe, such as 'Violet de Provence' and 'Blanca de Tudela'. 'Opal $F_{1}$ ' is a commercial cultivar released by Nunhems (Nunhems BV, Haelen, the Netherlands), characterized by high productivity, contemporary harvests and good quality of heads for fresh consumption (Calabrese et al. 2004). The productive period of this cultivar starts in April and ends in May. These genotypes were chosen because of their different propagation methods: vegetative by 'ovoli' (dormant offshoots) in 'Violetto di Sicilia', by 'seeds' (achenes) in 'Opal F⿸' this strongly influences the globe artichoke root growth in the first stages and the overall rhizosphere dimension of the plant (Cosentino and Mauromicale 1990). Fifty-day-old seedlings at the stage of three to four true leaves ('Opal $\mathrm{F}_{1}$ ') and pre-sprouted 'ovoli' ('Violetto di Sicilia') were transplanted in the field on August 10, 2003 in a $0.80 \times 1.25-\mathrm{m}$ format $\left(10,000\right.$ plant $\left.\mathrm{ha}^{-1}\right)$. Each sub-sub-plot consisted of 30 plants. Prior to transplanting, tillage consisted of a $25-\mathrm{cm}$ depth ploughing followed by harrowing, while at the end of the first season (early June) plants were mowed at ground level. In the second season, the dried, 1-year-old crop was awakened on August 5, 2004 by drip irrigation until field capacity. In both growing seasons, drip irrigation was supplied starting from transplanting by providing $100 \%$ of maximum evapotranspiration (net of rain), when accumulated daily evaporation, from an unscreened class A-Pan evaporimeter situated near the crop, reached $40 \mathrm{~mm}$. Fertilization with $\mathrm{P}$ and $\mathrm{K}$ was done before transplanting (season I) or crop re-growth (season II), incorporating into the top $20-\mathrm{cm}$ soil layer triple superphosphate $\left(46 \% \mathrm{P}_{2} \mathrm{O}_{5}\right)$ and $200 \mathrm{~kg} \mathrm{ha}^{-1} \mathrm{~K}_{2} \mathrm{O}$ potassium sulphate $\left(51 \% \mathrm{~K}_{2} \mathrm{O}\right)$, respectively. $\mathrm{N}$ was applied by liquid fertilization eight times (in equal amounts every 25 days from late August until early December, and from mid-February until late April) in each growing season. A liquid fertilizer (Nitroplus $32^{\circledR}$ ) was used with a $32 \%$ of $\mathrm{N}$ concentration: $8 \%$ as nitrate, $8 \%$ as ammonium and $16 \%$ as urea. In each growing season, weeding and pest management were conducted as per local custom, and lateral offshoots were removed twice, in early November and mid-February, leaving only one offshoot per plant. Plants of both genotypes were not treated with gibberellic acid.

\subsection{Data collection}

Meteorological conditions (maximum and minimum air temperature, relative humidity, rainfall) were monitored during the trial by a meteorological station (Mod. Multirecorder 2.40; ETG, Firenze, Italy) sited at the experimental field. Heads (main and secondary) were harvested on a weekly (autumn and winter) or 4 days (spring) basis at marketable stage and weighed without floral stems to determine their fresh weight. Then, subsamples of 20 main and secondary heads per plot were oven-dried at $105^{\circ} \mathrm{C}$ for $72 \mathrm{~h}$ to determine their dry weight. At the end of season II, five plants per sub-sub-plot were eradicated from the soil leaving the roots as undamaged as possible. Roots were then detached from the other plant parts, gently washed in tap water to remove soil residues and weighed. Five root samples per sub-plot, $50 \mathrm{~g}$ each, were oven-dried at $105^{\circ} \mathrm{C}$ until constant weight, then reweighed in order to determine the root dry weight per plant.

In both seasons, the following variables were calculated: earliness (as an index of commercial competitiveness of the crop, and expressed as number of heads collected at 31 December and 31 March in 'Violetto di Sicilia' and 'Opal $\mathrm{F}_{1}$ ', respectively, according to their different timing of floral induction and head ripening), total yield, expressed both as $\mathrm{t}$ fresh weight $(\mathrm{FW})$ of heads $\mathrm{ha}^{-1}$, and number of heads $\mathrm{ha}^{-1}$. The efficiency of $\mathrm{N}$ and $\mathrm{P}$ fertilization was calculated in terms of factors productivity, which were calculated according to the following equations: $\mathrm{PFP}_{\mathrm{N}}=\mathrm{Y}_{\mathrm{N}} / \mathrm{N}_{\mathrm{F}} \mathrm{TFP}=$ $\mathrm{Y}_{\mathrm{NPK}} / \mathrm{NPK}_{\mathrm{F}}$ where $\mathrm{PFP}_{\mathrm{N}}$ and TFP are the partial factor productivity of nitrogen and total factor productivity (nitrogen+phosphorus+potassium), respectively; $\mathrm{Y}_{\mathrm{N}}$ and $\mathrm{Y}_{\mathrm{NPK}}$ are the heads yield (expressed as $\mathrm{kg} \mathrm{ha}^{-1}$ on a dry weight basis) of the $\mathrm{N}$ - and $\mathrm{N}+\mathrm{P}_{2} \mathrm{O}_{5}+\mathrm{K}_{2} \mathrm{O}$-fertilized plots, respectively; $\mathrm{N}_{\mathrm{F}}$ and $\mathrm{NPK}_{\mathrm{F}}$ represent the amount of $\mathrm{N}$ and $\mathrm{N}+\mathrm{P}_{2} \mathrm{O}_{5}+\mathrm{K}_{2} \mathrm{O}$ applied units, respectively (expressed as $\mathrm{kg} \mathrm{ha}^{-1}$ ).

Moreover, for nitrogen fertilization, the agronomic efficiency $\left(\mathrm{N}_{\mathrm{AE}}\right)$ was calculated according to the following equation $\mathrm{N}_{\mathrm{AE}}=\left(\mathrm{Y}_{\mathrm{N}}-\mathrm{Y}_{0}\right) / \mathrm{N}_{\mathrm{F}}$ where $\mathrm{Y}_{\mathrm{N}}$ represents the heads yield of the $\mathrm{N}$-fertilized plot (expressed as $\mathrm{kg}$ dry weight $\left.\mathrm{ha}^{-1}\right), \mathrm{Y}_{0}$ is the heads yield of the N-unfertilized plot (control), and $\mathrm{N}_{\mathrm{F}}$ represents the amount of $\mathrm{N}$ applied (expressed as $\mathrm{kg} \mathrm{ha}^{-1}$ ) in fertilized plots.

\subsection{Statistical analysis}

Data collected were first submitted to Bartlett's test to check the homoscedasticity, then analyzed through a four-way (phosphorus rate $\times$ nitrogen rate $\times$ genotype $\times$ season) factorial analysis of variance (ANOVA). Commercial earliness, for each genotype, was subjected to a three-way (phosphorus rate $\times$ nitrogen rate $\times$ season) ANOVA, 
according to the different harvest period of the two genotypes tested. Provided that the $F$ test was significant, means were separated on the basis of Fisher's protected least significant difference test. All calculations were performed using CoStat ${ }^{\circledR}$ version 6.003 (Cohort Software, Monterey, CA, USA).

\section{Results and discussion}

\subsection{Weather conditions}

Total rainfall in the 2003-2004 growing season was rather low $(328 \mathrm{~mm})$, the majority of which $(211 \mathrm{~mm})$ fell mostly between October and March. The 2004-2005 growing season was more rainy, as the rainfall amount was $572 \mathrm{~mm}$, and almost $80 \%$ of it $(440 \mathrm{~mm})$ fell between October and February. Both growing seasons were characterized by similar maximum and minimum temperatures, which progressively decreased passing from August (on the average of both growing seasons $32.0^{\circ} \mathrm{C}$ and $20.6^{\circ} \mathrm{C}$, respectively) to January $\left(15.3^{\circ} \mathrm{C}\right.$ and $7.8^{\circ} \mathrm{C}$, respectively), and thereafter increased until May $\left(24.3^{\circ} \mathrm{C}\right.$ and $15.4^{\circ} \mathrm{C}$, respectively; data not shown).

\subsection{Earliness}

$\mathrm{N}$ supply strongly affected earliness of both genotypes (Table 1). As compared to control $\left(\mathrm{N}_{0}\right)$, earliness increased up to $\mathrm{N}_{300}$ in 'Violetto di Sicilia' (from 26,700 to 34,600 heads $\mathrm{ha}^{-1}$ harvested at 31 December), and up to $\mathrm{N}_{150}$ in 'Opal $\mathrm{F}_{1}$ ' (from 12,400 to 18,900 heads $\mathrm{ha}^{-1}$ harvested at $31 \mathrm{March}$ ) and also showed a significant decrease at higher $\mathrm{N}$ supplies (Table 1). These results substantially confirm previous researches conducted in different productive areas, which found the $142-285 \mathrm{~kg} \mathrm{Nha}^{-1}$ to be the optimal range for improving globe artichoke earliness (Elia and Conversa 2007), highlighting to a strong genetic component influencing the most appropriate $\mathrm{N}$ dose able to optimize the earliness of the crop. The highest $\mathrm{P}$ supply did not affect earliness per se (Table 1), but it significantly modified the response of both genotypes to the $\mathrm{N}$ supply (Fig. 1). In 'Violetto di Sicilia' at $\mathrm{P}_{50}$, earliness increased from $\mathrm{N}_{0}$ to $\mathrm{N}_{150}$ (from 25,000 to 30,100 heads $\mathrm{ha}^{-1}$ harvested at 31 December) and from $\mathrm{N}_{300}$ to $\mathrm{N}_{450}$ (from 31,000 to 36,000 heads $\mathrm{ha}^{-1}$ harvested at 31 December), while at $\mathrm{P}_{150}$ it increased from $\mathrm{N}_{0}$ to $\mathrm{N}_{300}$ (from 28,500 to 37,900 heads $\mathrm{ha}^{-1}$ harvested at 31 December), then sharply decreased at $\mathrm{N}_{450}\left(25,800\right.$ heads $\mathrm{ha}^{-1}$ harvested at 31 December; Fig. 1a). In 'Opal $F_{1}$ ', the $P_{150}$ supply significantly improved earliness at $\mathrm{N}_{150}$ (19,800 heads $\mathrm{ha}^{-1}$ harvested at 31 March) as compared with the same $\mathrm{N}$ supply at $\mathrm{P}_{50}\left(16,900\right.$ heads ha ${ }^{-1}$ harvested at $\left.31 \mathrm{March}\right)$,
Table 1 Earliness ( 000 heads per hectare harvested at 31 December and 31 March in 'Violetto di Sicilia' and 'Opal $F_{1}$ ', respectively) as affected by the main factors

\begin{tabular}{ccc}
\hline Treatment & Violetto di Sicilia & Opal $\mathrm{F}_{1}$ \\
\hline Phosphorus rate & & \\
$\mathrm{P}_{50}$ & $30.5 \mathrm{a}$ & $15.3 \mathrm{a}$ \\
$\mathrm{P}_{150}$ & $31.5 \mathrm{a}$ & $15.7 \mathrm{a}$ \\
$F$ & $0.6^{\mathrm{NS}}$ & $0.3^{\mathrm{NS}}$ \\
Nitrogen rate & & \\
$\mathrm{N}_{0}$ & $26.7 \mathrm{c}$ & $12.4 \mathrm{c}$ \\
$\mathrm{N}_{150}$ & $31.9 \mathrm{ab}$ & $18.9 \mathrm{a}$ \\
$\mathrm{N}_{300}$ & $34.6 \mathrm{a}$ & $15.9 \mathrm{~b}$ \\
$\mathrm{~N}_{450}$ & $30.7 \mathrm{~b}$ & $14.8 \mathrm{~b}$ \\
$F$ & $7.0^{* *}$ & $14.6^{* * *}$ \\
Season & & $14.9 \mathrm{a}$ \\
Season I & $29.8 \mathrm{a}$ & $16.1 \mathrm{a}$ \\
Season II & $32.2 \mathrm{a}$ & $2.7^{\mathrm{NS}}$ \\
$F$ & $3.6^{\mathrm{NS}}$ &
\end{tabular}

$F$ Fisher-Snedecor test, $N S$ not significant

Different letters within each column's factor indicate significance at Fisher's protected least significant difference test $(P \leq 0.05)$

$* * P \leq 0.01 ; * * * P \leq 0.001$ (significant)

but it also caused a more marked earliness reduction (by up to 5,800 heads $\mathrm{ha}^{-1}$ harvested at 31 March) from $\mathrm{N}_{150}$ to $\mathrm{N}_{450}$ (Fig. 1b). The significant $\mathrm{P} \times \mathrm{N}$ interaction affecting earliness confirms the primary role of the available $\mathrm{P}$ in the soil in influencing the crop response to the $\mathrm{N}$ supply (Zubillaga et al. 2002). Under P-limited conditions both genotypes showed higher $\mathrm{N}$ demand in order to maximize their earliness, so suggesting an inefficient $\mathrm{N}$ use of the crop which is often at the root of its heavy overdressing in ordinary field conditions. Indeed, the highest $\mathrm{P}$ rate significantly lowered the N/P ratio of applied fertilization units, able to optimize earliness, regardless of genotype, from 7.5:1 to $1.5: 1$. This has implications from an environmental point of view, as it suggests that an adequate $\mathrm{P}$ supply allows a better $\mathrm{N}$ fertilization management of the crop without compromising its earliness, when this trait has a key role for its commercial success.

\subsection{Total yield and its components}

Total yield was responsive to the $\mathrm{N}$ supply, increasing by up to $48 \%$ (from 11.1 to $16.4 \mathrm{t} \mathrm{FW}$ heads $\mathrm{ha}^{-1}$ ) from $\mathrm{N}_{0}$ to $\mathrm{N}_{300}$ (Table 2). This resulted from the increase of both, the number of heads per hectare and the weight of main and secondary heads, which, within the same $\mathrm{N}$ range, increased by up to 42,700 heads $\mathrm{ha}^{-1}, 20 \mathrm{~g}$ and $22 \mathrm{~g}$, respectively (Table 2). For all these variables, the highest $\mathrm{N}$ supply, namely $\mathrm{N}_{450}$, exerted no significant effects (Table 2 ). 
a

Earliness (000 heads ha ${ }^{-1}$ )

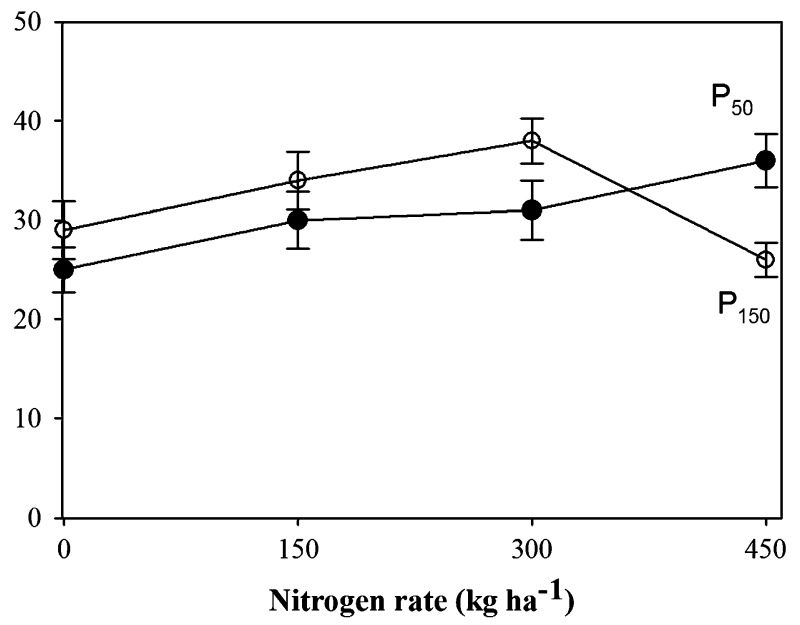

b

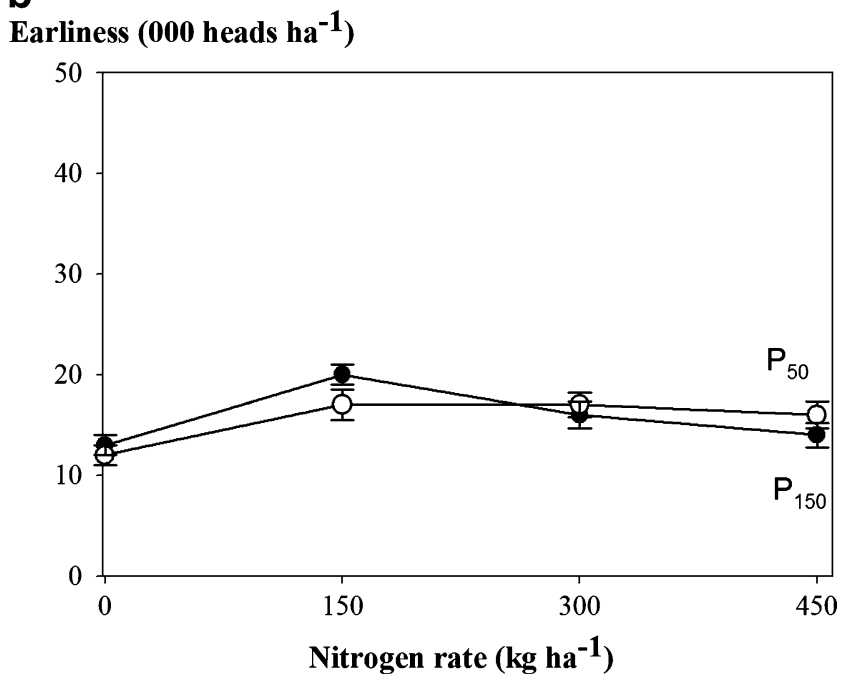

Fig. 1 Earliness in Violetto di Sicilia (a) and Opal $F_{1}(\mathbf{b})$ as affected by 'phosphorus rate $\mathrm{x}$ nitrogen rate' interaction. LSD interaction at $P=$ 0.05 was 3.1 for Violetto di Sicilia and 2.2 for Opal $F_{1}$. Vertical bars indicate the standard error of the mean. Solid circle represents $\mathrm{P}_{50}$; open circle represents $\mathrm{P}_{150}$

Root dry weight increased from $\mathrm{N}_{0}$ to $\mathrm{N}_{300}$ (from 82 to 127 g per plant) but decreased at $\mathrm{N}_{450}$ (Table 2). 'Opal $\mathrm{F}_{1}$ ', as compared to 'Violetto di Sicilia', showed higher values of total yield (17.3 vs. 11.6 t FW ha ${ }^{-1}$ ) and number of heads per hectare $(103,800$ vs. 86,100$)$, and weight of heads, main (202 vs. $157 \mathrm{~g}$ ) and secondary (164 vs. $138 \mathrm{~g}$; Table 2); it also showed the highest root dry weight (113 vs. $91 \mathrm{~g}$ per plant; Table 2).

Analysis of variance also showed a significant interaction among $\mathrm{N}$ and $\mathrm{P}$ supplies as well as among $\mathrm{P}$ supply and season on total yield and number of heads per hectare. In the absence of $\mathrm{N}$ fertilization, the increase in $\mathrm{P}$ supply from 50 to $150 \mathrm{~kg} \mathrm{ha}^{-1}$ significantly reduced yield from 12.0 to $10.2 \mathrm{t} \mathrm{FW}$ heads ha ${ }^{-1}$ (Table 3 ). On the contrary, the response of both total yield and number of heads per hectare to the growing $\mathrm{N}$ supply was more marked at $\mathrm{P}_{150}$ than at $\mathrm{P}_{50}$. Indeed, passing from $\mathrm{N}_{0}$ to $\mathrm{N}_{300}$ they showed at $\mathrm{P}_{150}$ a steeper increase (from 10.2 to $17.5 \mathrm{t} \mathrm{FW} \mathrm{ha}{ }^{-1}$ and from 66,000 to 115,300 heads $\mathrm{ha}^{-1}$, respectively) as compared to the same $\mathrm{N}$ doses at $\mathrm{P}_{50}$ (where they increased from 12.0 to $15.2 \mathrm{t} \mathrm{FW}$ heads $\mathrm{ha}^{-1}$ and from 68,200 to 104,300 heads $\mathrm{ha}^{-1}$, respectively), but both variables showed a higher decrease as the $\mathrm{N}$ supply passed from $\mathrm{N}_{300}$ to $\mathrm{N}_{450}$ (Table 3). Moreover, at $\mathrm{P}_{150}$ both total yield and number of heads per hectare proved a good stability across seasons, while at $\mathrm{P}_{50}$ they showed a significant decrease passing from season I to season II (Table 3).

$\mathrm{N}$ and $\mathrm{P}$ are known to optimize the plant's photosynthetic, growth and developmental processes, with P playing a central role in determining the efficiency with which solar energy is accumulated and converted into new biomass (Zubillaga et al. 2002). However, the results of this experiment show a marked effect of the available $\mathrm{P}$ in the soil on determining the crop's response to the $\mathrm{N}$ fertilization. This resulted particularly evident by the strong interaction between $\mathrm{P}$ and $\mathrm{N}$ in relation to total yield. Indeed, under $\mathrm{N}$-deficient conditions, the highest $\mathrm{P}$ rate reduced the total yield of the crop. This could be due to the peculiar synergism between $\mathrm{N}$ and $\mathrm{P}$ within the plant, since, according to Ashraf et al. (2001), the critical deficiency level of $\mathrm{N}$ increases as the $\mathrm{P}$ content increases and vice versa. On the contrary, the highest $\mathrm{P}$ availability acted to significantly improve the yield response of the crop to the growing $\mathrm{N}$ supply, especially within the $\mathrm{N}_{150}-\mathrm{N}_{300}$ interval. As a consequence, a substantial equivalence emerged among the total yield recorded at $\mathrm{P}_{50} \mathrm{~N}_{300}$ and $\mathrm{P}_{150} \mathrm{~N}_{150}$, highlighting that, beyond the $\mathrm{N}_{150}$ level, increased $\mathrm{P}$ supply reduces the plant's need for $\mathrm{N}$; this suggests that up to $150 \mathrm{~kg} \mathrm{Nha}^{-1}$ dressing can be avoided by ensuring an adequate available $\mathrm{P}$ in the soil without causing total yield decreases. Moreover, under $\mathrm{P}_{50}$ conditions, the yield performance of the crop was reduced across seasons, suggesting that a progressive exacerbation of the $\mathrm{P}$ deficiency in the soil could be a component of soil weakness often observed in multiannual globe artichoke cultivations.

Overall, these results show that, in non-limiting $\mathrm{P}$ conditions, producers could opt for a significant reduction in the $\mathrm{N}$ supply to the crop, from 450 to $300 \mathrm{~kg} \mathrm{ha}^{-1}$ in order to maximize and stabilize over seasons the yield of the crop, or from 300 to $150 \mathrm{~kg} \mathrm{ha}^{-1}$ to obtain satisfactory yields and ensure, at the same time, a more environmentfriendly management of $\mathrm{N}$.

\subsection{Nutrient efficiency indices}

$\mathrm{P}$ and $\mathrm{N}$ levels significantly affected almost all the nutrient efficiency indices (Table 2). The highest $\mathrm{P}$ supply acted to 
Table 2 Bio-agronomical variables and nutrient efficiency indices of globe artichoke as affected by the main factors

\begin{tabular}{|c|c|c|c|c|c|c|c|c|}
\hline \multirow[t]{2}{*}{ Treatment } & \multirow{2}{*}{$\begin{array}{l}\text { Total yield } \\
(\mathrm{t} \mathrm{FW} \mathrm{ha-1)}\end{array}$} & \multirow{2}{*}{$\begin{array}{l}\text { Number } \\
\text { of heads } \\
\left(000 \mathrm{ha}^{-1}\right)\end{array}$} & \multicolumn{2}{|c|}{ Heads fresh weight } & \multirow{2}{*}{$\begin{array}{l}\text { Root weight } \\
\left.\text { (g DW plant }^{-1}\right)\end{array}$} & \multirow{2}{*}{$\begin{array}{l}\mathrm{PFP}_{\mathrm{N}} \\
\left(\mathrm{kg} \mathrm{ha}^{-1}\right. \\
\left.\mathrm{DW} \mathrm{kg}{ }^{-1}\right)\end{array}$} & \multirow{2}{*}{$\begin{array}{l}\mathrm{N}_{\mathrm{AE}} \\
\left(\Delta \mathrm{kg} \mathrm{ha}^{-1}\right. \\
\left.\mathrm{DW} \mathrm{kg}{ }^{-1}\right)\end{array}$} & \multirow{2}{*}{$\begin{array}{l}\text { TFP } \\
\left(\mathrm{kg} \mathrm{ha}^{-1}\right. \\
\left.\text { DW kg }{ }^{-1}\right)\end{array}$} \\
\hline & & & Main (g) & Secondary (g) & & & & \\
\hline \multicolumn{9}{|l|}{ Phosphorus rate } \\
\hline $\mathrm{P}_{50}$ & $14.3 \mathrm{a}$ & $94.0 \mathrm{a}$ & $181 \mathrm{a}$ & $155 \mathrm{a}$ & $87 \mathrm{~b}$ & $6.4 \mathrm{~b}$ & $1.0 \mathrm{~b}$ & $3.3 \mathrm{a}$ \\
\hline $\mathrm{P}_{150}$ & $14.6 \mathrm{a}$ & $95.9 \mathrm{a}$ & $178 \mathrm{a}$ & $147 \mathrm{a}$ & $117 \mathrm{a}$ & $6.9 \mathrm{a}$ & $2.5 \mathrm{a}$ & $3.1 \mathrm{a}$ \\
\hline$F$ & $0.6^{\mathrm{NS}}$ & $1.4^{\mathrm{NS}}$ & $1.0^{\mathrm{NS}}$ & $2.3^{\mathrm{NS}}$ & $161.2 * * *$ & $6.1^{*}$ & $125.6^{* * *}$ & $2.4^{\mathrm{NS}}$ \\
\hline \multicolumn{9}{|l|}{ Nitrogen rate } \\
\hline $\mathrm{N}_{0}$ & $11.1 \mathrm{c}$ & $67.1 \mathrm{c}$ & $164 \mathrm{c}$ & $142 \mathrm{~b}$ & $82 \mathrm{c}$ & - & - & $4.2 \mathrm{a}$ \\
\hline $\mathrm{N}_{150}$ & $14.0 \mathrm{~b}$ & $96.2 \mathrm{~b}$ & $175 \mathrm{~b}$ & $145 \mathrm{~b}$ & $87 \mathrm{c}$ & $10.1 \mathrm{a}$ & $2.1 \mathrm{a}$ & $3.4 \mathrm{~b}$ \\
\hline $\mathrm{N}_{300}$ & $16.4 \mathrm{a}$ & $109.8 \mathrm{a}$ & $184 \mathrm{ab}$ & $164 \mathrm{a}$ & $127 \mathrm{a}$ & $5.9 \mathrm{~b}$ & $1.9 \mathrm{a}$ & $2.9 \mathrm{c}$ \\
\hline $\mathrm{N}_{450}$ & $16.3 \mathrm{a}$ & $106.6 \mathrm{a}$ & $194 \mathrm{a}$ & $153 \mathrm{ab}$ & $112 \mathrm{~b}$ & $3.9 \mathrm{c}$ & $1.3 \mathrm{~b}$ & $2.4 \mathrm{~d}$ \\
\hline$F$ & $74.6 * * *$ & $133.3 * * *$ & $12.4 * * *$ & $4.8 * *$ & $4.6 * *$ & $448.4 * * *$ & $13.8^{* * *}$ & $107.0 * * *$ \\
\hline \multicolumn{9}{|l|}{ Genotype } \\
\hline Violetto di Sicilia & $11.6 \mathrm{~b}$ & $86.1 \mathrm{~b}$ & $157 \mathrm{~b}$ & $138 \mathrm{~b}$ & $91 \mathrm{~b}$ & $5.2 \mathrm{~b}$ & $1.8 \mathrm{a}$ & $2.4 \mathrm{~b}$ \\
\hline Opal F 1 & $17.3 \mathrm{a}$ & $103.8 \mathrm{a}$ & $202 \mathrm{a}$ & $164 \mathrm{a}$ & $113 \mathrm{a}$ & $8.1 \mathrm{a}$ & $1.8 \mathrm{a}$ & $4.0 \mathrm{a}$ \\
\hline$F$ & $391.2 * * *$ & $110.2 * * *$ & $155.7 * * *$ & $32.9 * * *$ & $104.1 * * *$ & $287.7 * * *$ & $0.9^{\mathrm{NS}}$ & $425.0 * * *$ \\
\hline \multicolumn{9}{|l|}{ Season } \\
\hline Season I & $14.8 \mathrm{a}$ & $97.2 \mathrm{a}$ & $179 \mathrm{a}$ & $145 \mathrm{a}$ & - & $6.8 \mathrm{a}$ & $1.9 \mathrm{a}$ & $3.0 \mathrm{a}$ \\
\hline Season II & $14.1 \mathrm{a}$ & $92.7 \mathrm{a}$ & $180 \mathrm{a}$ & $157 \mathrm{a}$ & - & $6.5 \mathrm{a}$ & $1.7 \mathrm{a}$ & $3.2 \mathrm{a}$ \\
\hline$F$ & $1.7^{\mathrm{NS}}$ & $0.8^{\mathrm{NS}}$ & $0.1^{\mathrm{NS}}$ & $2.8^{\mathrm{NS}}$ & & $2.1^{\mathrm{NS}}$ & $1.6^{\mathrm{NS}}$ & $2.3^{\mathrm{NS}}$ \\
\hline
\end{tabular}

$F$ Fisher-Snedecor test, $N S$ not significant, $P F P N$ Partial factor productivity of nitrogen, $N A E$ Nitrogen agronomic efficiency, $T F P$ Total factor productivity

Different letters within each column's factor indicate significance at Fisher's protected least significant difference test $(P \leq 0.05)$

$* P \leq 0.05 ; * * P \leq 0.01 ; * * * P \leq 0.001$ (significant)

Table 3 Total yield, number of heads and nitrogen agronomic efficiency $\left(\mathrm{N}_{\mathrm{AE}}\right)$ as affected by 'phosphorus rate $\mathrm{x}$ nitrogen rate' and 'phosphorus rate $\times$ season' interactions

\begin{tabular}{|c|c|c|c|c|c|c|}
\hline & $\mathrm{P}_{50}$ & $\mathrm{P}_{150}$ & $\mathrm{P}_{50}$ & $\mathrm{P}_{150}$ & $\mathrm{P}_{50}$ & $\mathrm{P}_{150}$ \\
\hline & \multicolumn{2}{|c|}{ Total yield (t FW ha ${ }^{-1}$ ) } & \multicolumn{2}{|c|}{ Number of heads $\left(000 \mathrm{ha}^{-1}\right)$} & \multicolumn{2}{|c|}{$\mathrm{N}_{\mathrm{AE}}\left(\Delta \mathrm{kg} \mathrm{ha}^{-1} \mathrm{DW} \mathrm{kg}{ }^{-1}\right)$} \\
\hline \multicolumn{7}{|l|}{ Nitrogen rate } \\
\hline $\mathrm{N}_{0}$ & 12.0 & 10.2 & 68.2 & 66.0 & - & - \\
\hline $\mathrm{N}_{150}$ & 13.8 & 14.2 & 95.9 & 96.5 & 1.0 & 3.2 \\
\hline $\mathrm{N}_{300}$ & 15.2 & 17.5 & 104.3 & 115.3 & 1.0 & 2.8 \\
\hline $\mathrm{N}_{450}$ & 16.0 & 16.5 & 107.6 & 105.6 & 0.9 & 1.7 \\
\hline$F$ & $12.5^{* * *}$ & & $3.3^{*}$ & & $8.9^{*}$ & \\
\hline LSD interaction & 1.0 & & 6.7 & & 0.5 & \\
\hline \multicolumn{7}{|l|}{ Season } \\
\hline 2003-2004 & 14.7 & 14.8 & 96.7 & 97.6 & 1.3 & 2.5 \\
\hline 2004-2005 & 13.7 & 14.4 & 91.0 & 94.3 & 0.7 & 2.6 \\
\hline$F$ & $5.0^{*}$ & & $15.6^{*}$ & & $16.7 *$ & \\
\hline LSD interaction & 0.6 & & 2.9 & & 0.4 & \\
\hline
\end{tabular}

$F$ Fisher-Snedecor test, $L S D$ Fisher's protected least significant difference $(P \leq 0.05)$

$* P \leq 0.05 ; * * * P \leq 0.001$ (significant) 
significantly increase both the partial factor productivity of $\mathrm{N}\left(\mathrm{PFP}_{\mathrm{N}}\right)$ and $\mathrm{N}$ agronomic efficiency $\left(\mathrm{N}_{\mathrm{AE}}\right)$, while the increasing $\mathrm{N}$ rate had a depressive effect on $\mathrm{PFP}_{\mathrm{N}}, \mathrm{N}_{\mathrm{AE}}$ and total factor productivity (TFP; Table 2). In particular, as the $\mathrm{N}$ supply increased from $\mathrm{N}_{150}$ to $\mathrm{N}_{450}$, the $\mathrm{N}_{\mathrm{AE}}$ reduction was higher at $\mathrm{P}_{150}$ (from 3.2 to $1.7 \Delta \mathrm{kg} \mathrm{ha}^{-1} \mathrm{DW} \mathrm{kg}{ }^{-1}$ ) than at $\mathrm{P}_{50}$ (from 1.0 to $0.9 \Delta \mathrm{kg} \mathrm{ha}^{-1} \mathrm{DW} \mathrm{kg}{ }^{-1}$; Table 3); on the contrary, passing from season I to season II the $\mathrm{N}_{\mathrm{AE}}$ reduction was more marked at $\mathrm{P}_{50}$ (from 1.3 to $0.7 \Delta$ $\mathrm{kg} \mathrm{ha}^{-1} \mathrm{DW} \mathrm{kg}{ }^{-1}$ ) while no significant variation was found at $\mathrm{P}_{150}$ (from 2.5 to $2.6 \Delta \mathrm{kg} \mathrm{ha}^{-1} \mathrm{DW} \mathrm{kg}{ }^{-1}$; Table 3). Moreover, as the $\mathrm{N}$ supply increased from $\mathrm{N}_{150}$ to $\mathrm{N}_{450}$ $\mathrm{PFP}_{\mathrm{N}}$ varied from 12.4 to $4.7 \mathrm{~kg} \mathrm{ha}^{-1} \mathrm{DW} \mathrm{kg}{ }^{-1}$ in 'Opal $\mathrm{F}_{1}$ ' and from 7.7 to $3.1 \mathrm{~kg} \mathrm{ha}^{-1} \mathrm{DW} \mathrm{kg}{ }^{-1}$ in 'Violetto di Sicilia'; similarly, within the $\mathrm{N}_{0}-\mathrm{N}_{450}$ range TFP decreased more markedly in 'Opal $\mathrm{F}_{1}$ ' (from 5.4 to $2.8 \mathrm{~kg} \mathrm{ha}^{-1}$ DW $\mathrm{kg}^{-1}$ ) than in 'Violetto di Sicilia' (from 3.0 to $1.9 \mathrm{~kg} \mathrm{ha}^{-1} \mathrm{DW} \mathrm{kg}{ }^{-1}$; Table 4). 'Opal $\mathrm{F}_{1}$ ' showed, also, the highest $\mathrm{N}_{\mathrm{AE}}$ increase passing from $\mathrm{P}_{50}$ to $\mathrm{P}_{150}$ (from 0.7 to $\left.2.9 \Delta \mathrm{kg} \mathrm{ha}^{-1} \mathrm{DW} \mathrm{kg}{ }^{-1},+314 \%\right)$ as compared to 'Violetto di Sicilia' (from 1.2 to $2.2 \Delta \mathrm{kg} \mathrm{ha}^{-1} \mathrm{DW} \mathrm{kg}{ }^{-1}$, $+83 \%$; data not shown).

Partial factor productivity is a physical parameter providing useful information about the nutrient use efficiency, as it quantifies total economic output relative to the utilization of all nutrient resources in the system (natural +external inputs; Cassman et al. 1996). Nitrogen agronomic efficiency represents the incremental efficiency of applied $\mathrm{N}$ as compared to unfertilized test and is proportional to the cost-benefit ratio from investment in $\mathrm{N}$ inputs (Novoa and Loomis 1981). We assume that, similarly to grain crops (Cassman et al. 1996; Yadav 2003; Bhattacharyya et al. 2008), it is possible to increase both partial factor productivity and agronomic efficiency (a) by increasing the uptake of indigenous nutrients and (b) by increasing the efficiency with which applied nutrients are taken up by crop and utilized to produce heads biomass. In relation to the first aspect, the adoption of the seed-propagated 'Opal $F_{1}$ ' allowed the maximization of both $\mathrm{PFP}_{\mathrm{N}}$ and TFP especially at the lowest $\mathrm{N}$ input levels. This is attributable to a higher root dry weight recorded in this experiment in 'Opal $\mathrm{F}_{1}$ ' in comparison to 'Violetto di Sicilia' which allowed a more efficient utilization of soil resources (namely water and soil minerals), confirming previous results on differences in the root characteristics between vegetatively propagated and seed propagated cultivars (Cosentino and Mauromicale 1990; Mauromicale and Ierna 1995). In relation to the second aspect, the highest $\mathrm{P}$ rate showed a marked synergistic effect with $\mathrm{N}$ fertilization, which resulted in a more stable response to the $\mathrm{N}$ supply over seasons, and an improved response to the $\mathrm{N}$ fertilization, especially within the $\mathrm{N}_{150}-\mathrm{N}_{300}$ window, where the highest $\mathrm{N}$ efficiency indices (namely $\mathrm{N}_{\mathrm{AE}}$ and $\mathrm{PFP}_{\mathrm{N}}$ ) were recorded, so emphasizing the inefficiency of increasing the $\mathrm{N}$ dressing beyond $\mathrm{N}_{300}$ in non-limiting $\mathrm{P}$ conditions.

\section{Conclusions}

In the present experiment, designed to study the effects of different nitrogen and phosphorus fertilization, it emerged that the combined effect of both macronutrient rates, rather than that of nitrogen or phosphorus per se, was pivotal in determining the agronomical behavior of the crop. In particular, by increasing the phosphorus rate from 50 to $150 \mathrm{~kg} \mathrm{P}_{2} \mathrm{O}_{5} \mathrm{ha}^{-1}$, it was possible to decrease the nitrogen rate able to maximize the yield performances of the crop (from 450 to $300 \mathrm{~kg} \mathrm{ha}^{-1}$ ), and increasing at the same time the nutrient efficiency indices (namely partial factor productivity of nitrogen, nitrogen agronomic efficiency and total factor productivity). On the other hand, the 'seed'-propagated hybrid 'Opal $\mathrm{F}_{1}$ ', as compared to the vegetatively propagated 'Violetto di Sicilia', showed a better response to lower nitrogen supplies, especially in non-limiting phosphorus conditions, indicating its better ability to fit sustainable farming systems. Overall our data show that combining an adequate phosphorus fertilization, together with the adoption of cultivars characterized by more efficient response to nitrogen application, is a useful tool to improve the agronomic performances of the crop, ensuring, at the same time, a more environment-friendly nitrogen fertilization.
Table 4 Partial factor productivity of nitrogen $\left(\mathrm{PFP}_{\mathrm{N}}\right)$ and total factor productivity (TFP) as affected by 'genotype $\mathrm{x}$ nitrogen rate' interaction

$F$ Fisher-Snedecor test, $L S D$ Fisher's protected least significant difference $(P \leq 0.05)$ $* * * P \leq 0.001$ (significant)

\begin{tabular}{|c|c|c|c|c|}
\hline Nitrogen rate & $\begin{array}{l}\text { Violetto di Sicilia } \\
\operatorname{PFP}_{\mathrm{N}}\left(\mathrm{kg} \mathrm{ha}^{-1} \mathrm{DW} \mathrm{kg}^{-1}\right)\end{array}$ & Opal $F_{1}$ & $\begin{array}{l}\text { Violetto di Sicilia } \\
\text { TFP }\left(\mathrm{kg} \mathrm{ha}^{-1} \mathrm{DW} \mathrm{kg}^{-1}\right)\end{array}$ & Opal $F_{1}$ \\
\hline $\mathrm{N}_{0}$ & - & - & 3.0 & 5.4 \\
\hline $\mathrm{N}_{150}$ & 7.7 & 12.4 & 2.6 & 4.2 \\
\hline $\mathrm{N}_{300}$ & 4.6 & 7.2 & 2.3 & 3.6 \\
\hline $\mathrm{N}_{450}$ & 3.1 & 4.7 & 1.9 & 2.8 \\
\hline$F$ & $30.2 * * *$ & & $18.9^{* * *}$ & \\
\hline LSD interaction & 0.6 & & 0.5 & \\
\hline
\end{tabular}




\section{References}

Ashraf M, Shabaz M, Ashraf MY (2001) Influence of nitrogen supply and water stress on growth and nitrogen, phosphorus, potassium and calcium contents in pearl millet. Biol Plantarum 44:459-462

Basnizki Y, Zohary D (1994) Breeding of seed planted artichoke. Pl Breed Rev 12:253-269

Bhattacharyya R, Kundu S, Prakash V, Gupta HS (2008) Sustainability under combined application of mineral and organic fertilizers in a rainfed soybean-wheat system of the Indian Himalayas. Eur J Agron 28:33-46

Calabrese N, De Palma E, Bianco VV (2004) Yield and quality of new commercial seed grown artichoke hybrids. Acta Hort 660:7782

Cassman KG, Gines GC, Dizon MA, Samson MI, Alcantara JM (1996) Nitrogen-use efficiency in tropical lowland rice systems: contribution from indigenous and applied nitrogen. Field Crop Res 47:1-12

Cosentino S, Mauromicale G (1990) Transpiration and plant water status of globe artichoke (Cynara scolymus L.) grown from seed and from vegetative organs with two water regimes. Acta Hort 278:261-270

Ehaliotis C, Massas I, Pavlou G (2010) Efficient urea-N and $\mathrm{KNO}_{3}-\mathrm{N}$ uptake by vegetable plants using fertigation. Agron Sustain Dev 30:763-768

Elia A, Conversa G (2007) Mineral nutrition aspects in artichoke growing. Acta Hort 630:239-249

FAOSTAT (2008) Crops statistical database of the Food and Agriculture Organization of the United Nations. http://faostat. fao.org/. Assessed 18 February 2011

Foti S, Mauromicale G, Ierna A (2005) Response of seed-grown globe artichoke to different levels of nitrogen fertilization and water supplies. Acta Hort 681:237-242

Gonzalez-Dugo V, Durand JL, Gastal F (2010) Water deficit and nitrogen nutrition in of crops. A review. Agron Sustain Dev 30:529-544

Khayyo S, Pérez-Lotz J, Ramos C (2004) Application of the $\mathrm{N}_{\min }$ nitrogen fertilizer recommendation system in artichoke in the Valencian community. Acta Hort 660:261-266

Magnifico V (1987) Aspetti agronomici della coltivazione del carciofo. Inf Agr 43:57-66

Mauro R, Portis E, Acquadro A, Lombardo S, Mauromicale G, Lanteri S (2009) Genetic diversity of globe artichoke landraces from Sicilian small-holdings: implications for evolution and domestication of the species. Conserv Genet 10:431-440

Mauromicale G, Ierna A (1995) Effects of gibberellic acid and sowing date on harvesting time and yield of seed-grown globe artichoke (Cynara scolymus L.). Agronomie 15:527-538

Mauromicale G, Ierna A (2000) Characteristics of heads of seedgrown globe artichoke [Cynara cardunculus L. var. scolymus (L.) Fiori] as affected by harvest period, sowing date and gibberellic acid. Agronomie 20:197-204

Mauromicale G, Ierna A, Licandro P, Maugeri R, Scandurra S (2004) Il carciofo: una coltura "nuova" per la valorizzazione delle aree irrigue della collina interna siciliana. Italus Hortus 11:53-59

Novoa R, Loomis RS (1981) Nitrogen and plant production. Plant Soil 58:177-204

Pandino G, Courts FL, Lombardo S, Mauromicale G, Williamson G (2010) Caffeoylquinic acids and flavonoids in the immature inflorescence of globe artichoke, wild cardoon, and cultivated cardoon. J Agric Food Chem 58:1026-1031

Portis E, Mauromicale G, Barchi L, Mauro R, Lanteri S (2005) Population structure and genetic variation in autochthonous globe artichoke germplasm from Sicily Island. Plant Sci 168:15911598

Rincón L, Pérez A, Pellicer C, Abadia A, Sáez J (2007) Nutrient uptake by artichoke. Acta Hort 730:287-292

Ryan J (1998) Changes in organic carbon in long-term rotation and tillage trials in Northern Syria. In: Lal R, Kimble JM, Follett RF, Stewart BA (eds) Management of carbon sequestration in soil. Advances in Soil Science CRC Publisher, Boca Raton, pp 285 295

Ryan J, Masri S, Ceccarelli S, Grando S, Ibrikci H (2008) Differential responses of barley landraces and improved barley cultivars to nitrogen-phosphorus fertilizer. J Plant Nutr 31:381-393

Società Italiana Scienza del Suolo (1985) Metodi normalizzati di analisi del suolo. Edagricole, Bologna, p 100

Spiertz JHJ (2010) Nitrogen, sustainable agriculture and food security. A review. Agron Sustain Dev 30:43-55

White PJ, Brown PH (2010) Plant nutrition for sustainable development and global health. Ann Bot 105:1073-1080

Yadav RL (2003) Assessing on-farm efficiency and economics of fertilizer N, P and K in rice wheat systems of India. Field Crop Res 81:39-51

Zubillaga MM, Aristi JP, Lavado RS (2002) Effect of phosphorus and nitrogen fertilization on sunflower (Helianthus annus L.) nitrogen uptake and yield. J Agron Crop Sci 188:267-274 